\title{
Integrating Ergonomics in Maintanability: A Case Study from Manufacturing Industry
}

\author{
Kiumars Teymourian ${ }^{1}$, Dammika Seneviratne ${ }^{2}$ \\ and Diego Galar ${ }^{1,2}$ \\ ${ }^{1}$ Div. of Operation and Maintenance Engineering, Luleå University \\ of Technology, Sweden \\ ${ }^{2}$ Tecnalia Research and Innovation, La Almunia, Zaragoza, Spain \\ E-mail: kiumars.teymourian@ltu.se; dammika.seneviratne@tecnalia.com; \\ diego.galar@ltu.se
}

Received 01 October 2018;

Accepted 15 March 2019;

Publication 05 April 2019

\begin{abstract}
Maintainability is key part of Reliability, Availability, Maintainability and Safety (RAMS) estimation and prediction in complex assets. Indeed, availability calculation comprises accurate estimation of maintainability and frequently, it is just a time stamp for mean time to repair (MTTR) estimations. However, maintainability is a human related figure where the skill, capabilities, tools and the design of the asset play key role in its performance. The aim of this article is to describe the effects of ergonomists' contribution during maintainability process for system/products design. System designer thinking in system and its subsystem in a way of technical functionality. On the other hand, ergonomists are expertise in human capability and limitation. If human become a part of system than their interface and interaction become crucial factors in a success of system performance and its sustainability. In this paper, it has discussed three main issues that help the process of maintainability design. These issues are safety, task analysis and risk analysis. It has also touched reliability engineer's task to increase Overall Equipment Effectiveness (OEE). These issues are explained via a case study from a manufacturing industry.
\end{abstract}

Journal of Industrial Engineering and Management Science, Vol. 1, 131-150. doi: 10.13052/jiems2446-1822.2018.008

This is an Open Access publication. (c) 2019 the Author(s). All rights reserved. 
Keywords: Maintainability, Hierarchical Task Analysis (HTA), Ergonomics, Risk, Safety.

\section{Introduction}

The designers focus generally on the technical functionality of intended or requested system/products. As defined, system is a set of components that interact with each other in order to fulfill the required function or mission. One of the components of any system is human that have interact and interface with the system. On the other hand, ergonomists think to human abilities (both physical and mental) and their limitations when they become involved in the system or use of product. Today's system performance required many cognitive tasks load (it refers to the amount of cognitive workload which is the property of task) and cognitive workload (it refers to human mental effort and it is a property of an individual) activities [1]. Ergonomists are saying, "fitting the task to the man not vice versa" as discussed in Teymourian et al. [2]. The fusion of these two (designers and ergonomists) way of thinking during design process will lead to the concept of system thinking and emergence of human citizenship in the system. The more contemplated ergonomists in maintainability design process, the higher reliability, availability, maintainability and safety the system will have. Through these collaborations, the cap between Work-As-Done and Work-As-Imagine eliminates or become minimized Hollnagel, [3]. This cooperation will lead to have the collective conscious minds [4], which in turn lead to have the same understanding of entire system's functionalities and human factors. Peter Senge [5] indicated that understanding system is fundamental because larger system may drive in different way than our value. In other words, by faulty design system may have some negative side effects on workers/maintenance operator's health, safety, performance and internal as well as external environment. In maintainability management, safety engineers' involvement is one key issue as; O'Neill, [6], B. S. Dhillon, [7], B.S. Blanchard [8] pointed out. In this context, "Safety First" is the key issue of conceiving and perceiving human wellbeing in the sustainability of designed system/product. Designer together with the maintainability engineers planning many issues for their system/product and among them is the procedures for maintenance and its frequencies. Performing maintenance required through thorough tasks analysis, both technically and their related risks to human and its environment can be determined. To perform maintenance operations in a safe way it is essential to have an extensive 
knowledge about safety and the situation of an eventuality shortage in safety. It is also necessary to be aware of anatomy of an accident to control system and maintenance performances. Tasks need to be decomposed in hierarchical of subtask(s) for ensuring as much as possible things/performances go right.

\section{Background of the Case Study}

The integration of ergonomics in maintainability was studied through an automotive parts manufacturing company tools maintenance. One of the tasks performed by the tool maintainers is to separate a large tool, top from the bottom and then turn the top part, which is as shown in Figure 1. In this study the part of the upper tool that turned where investigated and is shown in Figure 2.

Maintainers have accessed to necessary information regarding, tool drawings and documents, work manuals, checklist, work procedures, work instructions at the level of operators and instructors, training for being qualified, special skill requirements, type of equipment and facilities, work place design, risk analysis, working alone, ergonomic evaluation, personal protective equipment (PPE) that had been prepared in advance. Environmental factors like temperature, working time, air quality, noise level, chemical substances that are crucial factors for tasks performance are in accordance with the governmental requirements. In some tasks or sub tasks it is required special skills for instance, crane driver in production department is not qualified for separating tools apart in maintenance workplace and they are qualified for

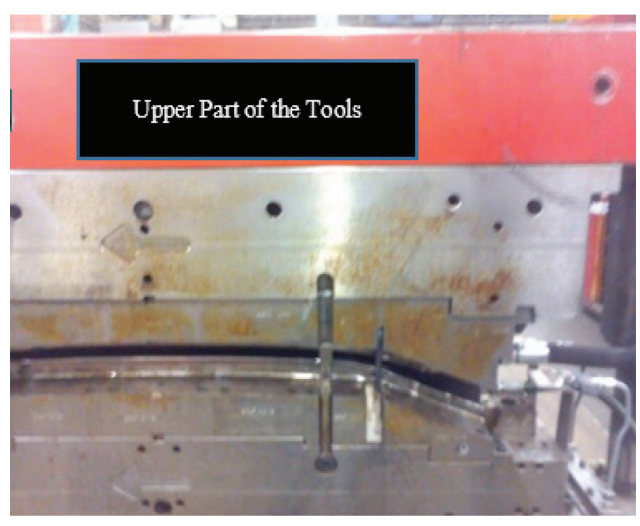

Figure 1 Separating tools. 


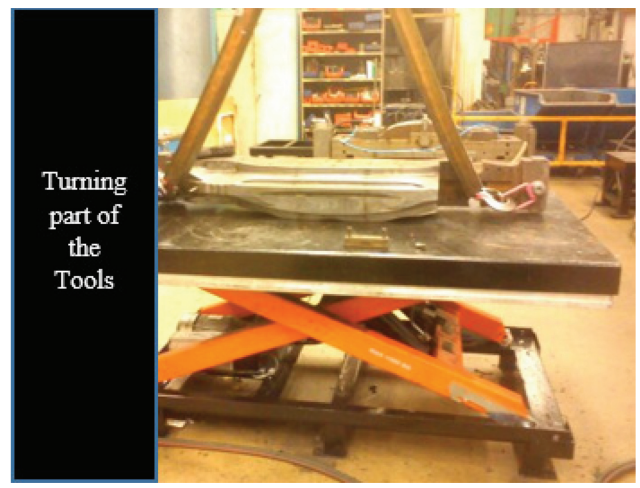

Figure 2 Turn part of the tool.

transporting objects/tools. Tool maintainers need to be specialized for not only transporting tools, but also how the heavy large tools should be separates and turns. The process of maintainability of the top part of the tool is analyzed based on the methodology explained in the Section 4.

\section{Methodology}

For the proposed case study described above, must be analyzed in such a way that ergonomics in represent in the maintainability. To analyze the proposed case, number of steps has been followed and is explain under this section.

\subsection{Reliability Engineers Task}

One of the reliability engineers' task during design of system or product is identifying the possibility of failures that may occur for system or product functionality. By identifying failures, potential accidental event, causal and its consequences will be evaluated by using different risk analysis tools such as fault tree, failure mode, effects and criticality analysis (FMECA), Event tree, etc. Marvin and Arnljot, each failure and its frequency leads to breakdown, to which influences system availability [9]. Vorne has classified six big losses on system performance [10]. Among them breakdown (others are; setup and adjustment, small stops reduce speed, startup rejects and production rejects). These losses in availability can be sporadic (well visible) and/or chronic (difficult to see). To minimize breakdown and other losses implementing of Total Productive Maintenance (TPM) or Productive Maintenance (PM) 
is key issue for increasing of Overall Equipment Effectiveness (OEE) of system/product. TPM or PM is based on involvement of all employees' activities for continuous improvement in maintenance performance [8]. List of failures and keeping system in function are a guideline for maintenance engineers in order to prepare different maintenance plans, preventive maintenance (all scheduled maintenance actions in order to keep system in its intended function), corrective maintenance (all unscheduled maintenance actions because of failures), predictive maintenance (it refers to condition monitoring of system in order to predicting the system degradation), maintenance prevention TPM (refers to the concept of maintenance free design with the objective of minimizing maintenance down time and reducing life cycle cost), adaptive maintenance (it is relating to the relevant software and changes in processing) perfective maintenance (it refers to computer software so that increasing performance, maintainability) [8].

\subsection{Safety}

What it means by safety? The following phrases:

- "have an expression of good wish";

- "as long as you are here you are safe".

First and second expressions describing tellers' feeling of hope for no any unexpected and unwanted events that can lead to adverse outcomes like as accidents, incidents or harms. However, interpretation of the last expression is, as long as you are here nothing bad will happen to you. Safety is a condition or state of being safe from undesirable events. In other words, have a feeling of being safe is the outcome of activities that we do will lead to an expected and success events, that is, things go right rather than go wrong or the number of adverse outcomes is as low as possible. Hollnagel [3] stated safety as dynamic non-event. Eurocontrol International Civil Aviation Organization (ICAO) defined safety as: "The state in which the possibility of harm to persons or of property damage is reduced to and maintained at or below, an acceptable level through a continuing process of hazard identification and safety risk management" [11]. People may have different perception concerning the presence of safety. It is necessary to know what the condition of becoming aware of or perceiving the presence of safety is. Hollnagel [3] described through intersubjective verification people can have the same understating for presence of safety. Intersubjective means, "Involving or occurring between separate conscious minds like, intersubjective communication [12]". 
Conscious mind according to Sigmund Freud consist of everything inside of our awareness and it includes sensations, perception, memories, feeling and fantasies. He often exemplified this to the tip of the iceberg (outside of water) [13]. Conscious minds are the hypothetical and transcendent consciousness that is created by fusing people's minds into a collective called as group mind [14]. Accident and incident (both from negative point of view) are the outcome of unwanted and unexpected events that caused from uncertainty, unpredictability and failures which is the reason of lacking in presence of safety. Accident defines as [15]: "an undesirable or unfortunate happening that occurs unintentionally and usually results in harm, injury, damage, or loss; casualty; mishap". The philosophical definition of accident [16]: (in Aristotelian thought) a property of a thing, which is not essential to its nature like, 'The new element is existence, which Avicenna regarded as an accident, a property of things.' Incident defines as 'a violent event or the occurrence of danger" [17]. Today and future technologies require new way of thinking about risks that can reduce safety. Recently, safety consider as two categories; Safety I and Safety II. Safety I defined as A state where as few things as possible go wrong. Safety II, ensuring that as many things as possible go right [11]. A White Paper that published by [11], describe, "Things go wrong due to technical, human and organizational causes - failures and malfunctions. Humans are therefore viewed predominantly as a liability or hazard". In Safety I (one), accidents investigate when it already had happened by identifying the sequence of events and risk analysis carried out to clarify the degree of danger. In the context of Safety I, system is decomposable in parts to find out the causes of accident, but it is not applicable for socio-technical system, human and organizational components. On the other hand, Safety II (two) is concerning in: variability of every day performance and human considered as resource needed in the system for trying to understand how components functioning correctly to answer why part/process is not functioning as it planned. Safety II view is investing in safety not as a cost rather as investing in productivity. In a complex system workers performance occur base on working conditions rather than what they had told to do. There are differences between blunt-end and sharp-end concerning how the task should performed. Blunt-end (managers, office staff) are those whose roles and procedures affect how performance should be done that called "Work-As-Imagined", while sharp-end are those who do the real performance and confronted to different risks. Sharp-end understood how things work and through adjusting their performance according to different situations, performing their task, that [3] described as, "Work-As-Done". Through participatory ergonomics approach 


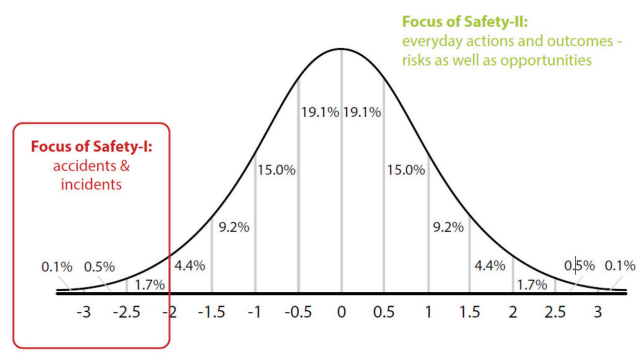

Figure 3 Events distribution [11].

[18] the gaps between Work-As-Imagined and Work-As-Done will be reduced or be eliminated. By knowing the differences between Safety, I and Safety II characteristics, it can be concluded that safety I focuses on the two side of events normal distribution. While Safety II concentrating in the middle of the same distribution (things go right) Figure 3. Improvement activities in Safety I will be too costly because of unexpected events. While improvement activities in Safety II are smaller and more continuous. These two methods can be used together as complementary to enhancing and improving safety in the system/product performances. In other words, moving from safety I concept to safety II will lead to make assured that system will function right.

\subsection{Task Analysis}

Today's tasks are form in such a complex set that required both physical and/or with many cognitive parts such as monitoring, predicting, anticipating and decision-making workload Annett, J., 2004 [19]. To do task analysis, it is necessary to apply relevant tools.

There are several methods that can be used for analyzing task: fault tree analysis (FTA), Event tree analysis (ETA) and so forth. Among them is Hierarchical Task Analysis (HTA) that applied in this paper. HTA method is top-down chain of process and it designed to walk-through the task, describing system's goals, sub-goals and plans. This method developed at University of Hull to analyze complex tasks [20]. HTA had been used for human factor and human computer interaction applications, including training by Shepher in 2002 [21], design by Lim and Long, 1994 [22], error and risk analysis by Baber and Stanton, 1994 [23] and team skills assessment by Annett et al., 2000 [24]. In the maintainability design process, HTA is an appropriate tool for analyzing the performance of operation and maintenance Energy Institute [25]. HTA is applicable at each six stage of maintainability process that 
Blanchard [8] described (conceptual design, preliminary system design, detail design and development, production and/or construction, system utilization and life-cycle support and system retirement and phase-out). HTA starts to describe the main goal as a set of sub operation. Each operation broken-down or decomposed in hierarchy form in order to sequences what sub performance should carried out. Operation or sub-operation can be break-down to such detail level that is necessary for starting task analysis. Stopping decomposing can be determined through the probability of failure $(\mathrm{P})$ times the cost of failure (C) at an approximate acceptable level $(\mathrm{P} \times \mathrm{C})$ Annett et al., 1971, [26]. HTA analyzes not by actions but it is a process for achieving operational goals [20]. Annett et al., 1971, [26] stated, three main principles determine HTA analysis; 1) it is necessary to consider each task formed of an operation and its intended operational goal in form of production, quality and other system requirement, 2 ) broking down each operation and its goal in sub-operation and sub-goal is a way for measuring their contribution to the overall system output, 3) the relationship made up of operations and sub-operation are hierarchical which means sub-goals have to be achieved sequentially, this cannot be always the case. Applying HTA as tool can show the root cause of existing failure or latent failure that can occur during performance. It also proposing solution for modification or redesigning of: equipment, work procedures, the type of required skill, training, support, risk analysis, and so forth. Stanton [27] also stated, "HTA should also serve as a benchmark for all other ergonomics methods and approaches and remain in the core repertoire for ergonomists".

\subsection{Risk Analysis}

Risk analysis is the one indispensable process after task analysis that designers and ergonomist compelled to perform it to secure task performance as safe as possible. For this purpose, there are several risk assessments methods in ergonomics: Rapid Upper Lim Assessment (RULA) [28], Quick Exposure Checklist (QEC) [29], Rapid Entire Body Assessment (REBA) [30], etc... Each of them has special quality and is strong manner. All these method needs to an additional risk analysis regarding health and safety for preventing incident and accident. William T. Fine [31] developed a mathematical evaluation for controlling hazard. His method gives a fast an overview of seriousness of hazards by calculating the score of risks which in turn calculated risk scores can be arranged in rank ordering to which one requiring most attention for corrective actions. Risk (R) calculation or risk score is a function of three 
factors: potential Severity or consequences (S) of an accident, the frequency of Exposure (E) to the hazard event and Probability (P) that hazard event will lead to the accident and its consequences.

$$
R=S \times E \times P
$$

Each factor has descriptions and numerical ratings. It recommends during maintainability design phase, maintenance engineer and ergonomist start to simulate; "work as-imagined" (idealistic view of formal task), ergonomic evaluation for workloads, health and safety [31] risk assessment and risk analysis. These simulations give an over view of an idealistic performance (work as imagined) and having a list of identified risks. By rank ordering risks list (descending/ascending number of product $R$ ) it helps to start to think what should be done (correct action), who is responsible for measuring, due date and action taken. Many of risks can be reduced or be eliminated before real work starts. The next step will be reevaluate risks in order to see the reduction of severities' degree. Identified risks have three alternative: eliminating, reducing or accept as it is. In the case of last two alternatives, it is obligatory to protect exposed staffs from risks by personal protective equipment and/or education and information. When the real task starts, there is a possibility that new or latent risks discover. In this situation, the earlier analyzed risk should be updated. Another advantage of W. Fine's method is the justification for recommended corrective action. Once the hazard identified and the cost of corrective action estimated it can calculate whether estimated cost is justified or not. The formula is:

$$
\begin{aligned}
\text { Justification }= & \frac{\text { severity } \times \text { exposure } \times \text { probability }}{\text { Cost factor } \times \text { Degree of correction }} \\
& J=\frac{S \times E \times P}{C F \times D C}
\end{aligned}
$$

Numerator is R, the product of severity or consequences (S), exposure (E) and probability (P). Denominator is, cost factor (CF) and degree of correction (DC) in percentage. Each factor in above formula has description and numerical rating. The criteria for justification rating is 10 that is, if planned corrective action is:

$$
\text { Justified }>10>\text { Not Justified }
$$

William Fine method used for tool maintainers. Three factors contributed in the degree of hazard seriousness: Severity (S), Exposure (E) and Probability (P). Table 1 shows five level of severities, description, lower and highest rates. 
Table 1 Severities levels

\begin{tabular}{clcc}
\hline & Description & 1 & 3 \\
S 1 & $\begin{array}{l}\text { Minor damage, minor cut, headache, bruises, damage that } \\
\text { can lead to less than 10 days sick absent. }\end{array}$ & $\begin{array}{c}\text { Highest } \\
\text { Rate }\end{array}$ \\
S 2 & $\begin{array}{l}\text { Burning damage, minor fractures, diseases with less } \\
\text { disability, asthma, sick leave between 10-60 days... }\end{array}$ & 3 & 8 \\
S 3 & $\begin{array}{l}\text { Fracture minor amputation, non-lethal poisoning, more than } \\
\text { 60 days sick leave. }\end{array}$ & 8 & 15 \\
S 4 & $\begin{array}{l}\text { Larger amputation (hands arm, legs, eyes) cancer, deadly } \\
\text { damage. }\end{array}$ & 15 & 30 \\
S 5 & 30 & 100 \\
\hline
\end{tabular}

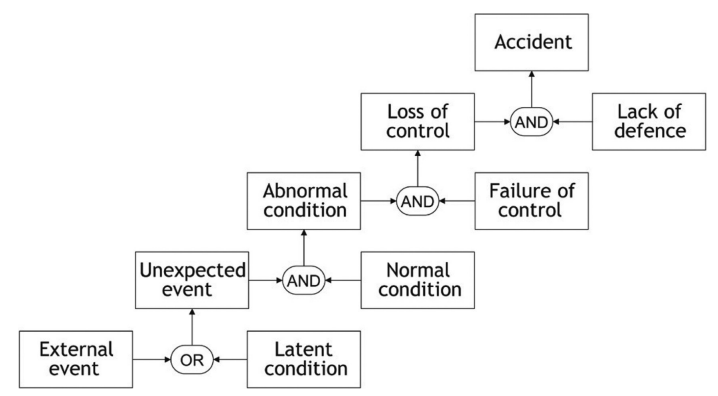

Figure 4 The anatomy of an accident Erik Hollnagel [3].

\section{Case Analysis}

Three main areas discussed in the methodology, safety, task analysis and risk analysis are investigated related to the industrial case. When considering safety, it is essential to be aware of connection and interaction between different elements in the system and make it easier to predict unexpected events, which can lead to accidents. This awareness will lead to take required measures also having control over things that should go right. Hollnagel, Erik [3] visualized the anatomy of occurrence of an accident as showed in Figure 4.

Through participatory ergonomics (Figure 5) approach [18] Work-AsImagined and Work-As-Done are two key issues that needs to be considered how real work should performed in safest way.

Concerning task performance, through hierarchical task analysis, each step of tasks and sub-task can be studied, and all possible risks and trainings can be identified and prepared. This process is shown in Figure 6. In this case separating and turning tool include of 17 or up to 20 sub tasks. 


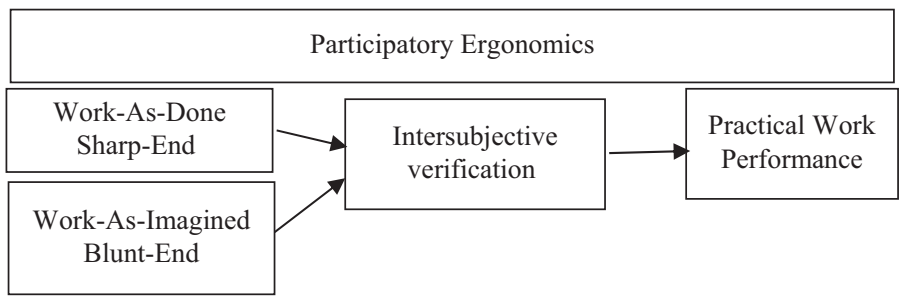

Figure 5 Participatory Ergonomics approach.

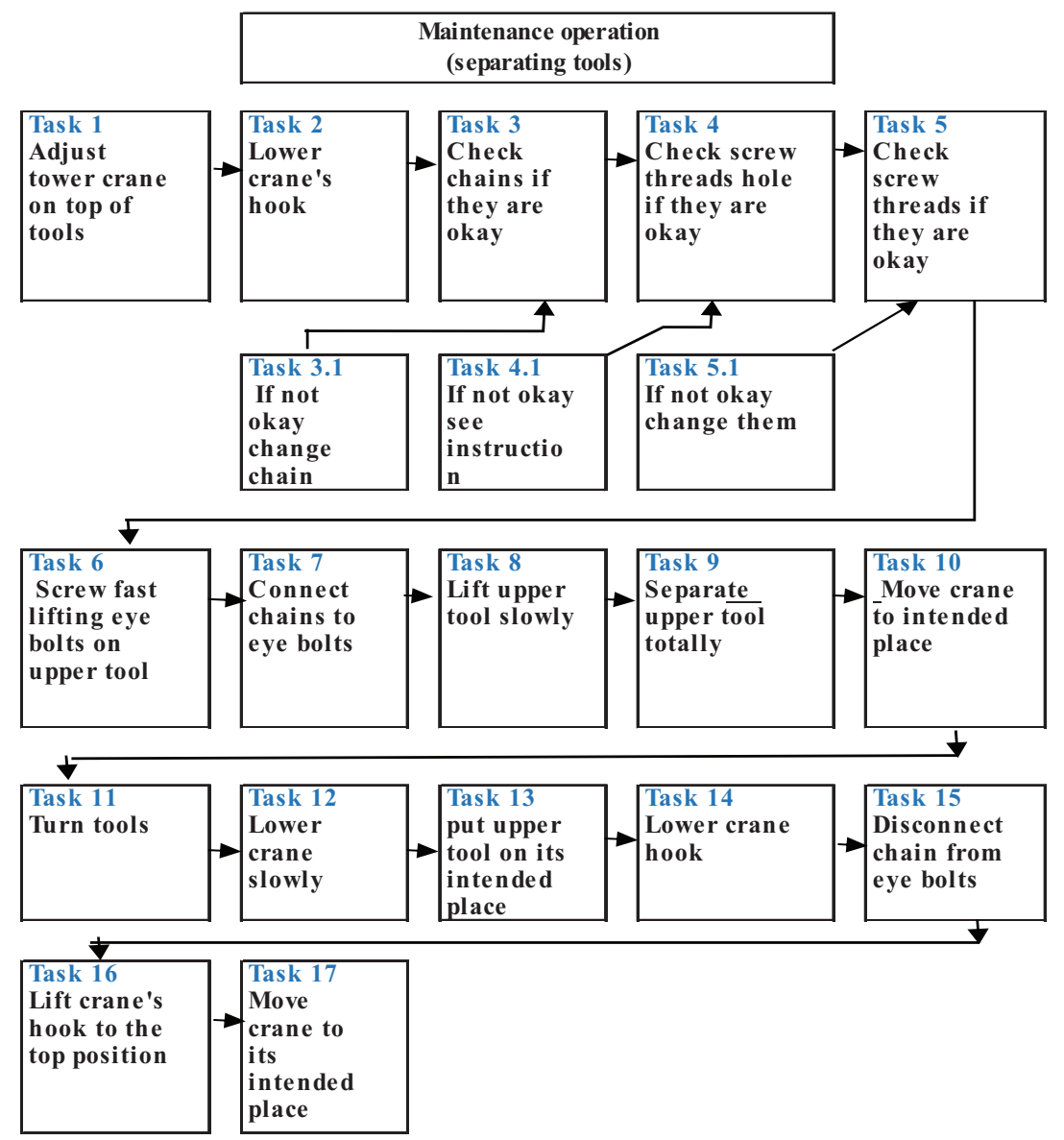

Figure 6 Hierarchical Task Analysis (HTA) for tool separation and overturn one part of tool performance. 
Table 2 Exposure time to the hazard event

\begin{tabular}{llcc}
\hline & Description & $\begin{array}{c}\text { Lower } \\
\text { Rate }\end{array}$ & $\begin{array}{c}\text { Highest } \\
\text { Rate }\end{array}$ \\
\hline E 1 & Very unlikely. It is not known that it may happen & 0,5 & 0,5 \\
E 2 & Possible. It is known that it may happen. & 1 & 1 \\
E 3 & Irregular. This can happen from once a year to once a month. & 2 & 3 \\
E 4 & Occasionally from once a month to once a week & 3 & 4 \\
E 5 & Common from once a week to once a day (shift) & 4 & 6 \\
E 6 & Often more than once a day (shift) & 6 & 8 \\
E 7 & continuously or many times per day & 8 & 10 \\
\hline
\end{tabular}

Table 3 Sequence of accident

\begin{tabular}{llcc}
\hline & Description & $\begin{array}{c}\text { Lower } \\
\text { Rate }\end{array}$ & $\begin{array}{c}\text { Highest } \\
\text { Rate }\end{array}$ \\
\hline P 1 & Very unlikely, but possible & 0,5 & 0,5 \\
P 2 & Unlikely, but possible & 1 & 1 \\
P 3 & Rare & 2 & 3 \\
P 4 & Often. It is likely that it occurs at 5-25\% of exposure & 3 & 4 \\
P 5 & Probably. It is likely that it occurs at 25-50\% of the & 4 & 6 \\
& $\begin{array}{l}\text { exposure times } \\
\text { P 6 }\end{array}$ & 8 & 10 \\
& Very probable. It is likely that it occurs at over 50\% of \\
\hline
\end{tabular}

Concerning risks analysis based on the William Fine method, there are three factors that contribute in the degree of hazard seriousness; Severity (S) Table 1, Exposure (E) Table 2 and Probability (P) Table 3. Each of them has descriptions, lower and highest scales.

Exposure start from very rarely to continuously or many times per day and its rating start from 0,5 to 10 . It classified in seven categories and provided in Table 2.

Probability is classified in six categories and its rating span is from 0,5 to 10 and shown in Table 3.

\section{Results}

Based on William Fine method severity (S) exposure (E) and probability (P) are calculated according tables; 1,2 and 3 . Table 4 shows the levels of severity for each identified risk.

$$
R=S \times E \times P
$$


Table 4 Shows the degree of severity (R) for four different level risks

\begin{tabular}{lcc}
\hline \multicolumn{3}{c}{ Degree of Severity $\mathrm{R}=\mathrm{S} \times \mathrm{E} \times \mathrm{P}$} \\
\hline & Lower Rate & Heights Rate \\
\hline No risk & 0,5 & 10 \\
Acceptable risk & 11 & 30 \\
Moderate risk & 31 & 100 \\
Serious risk & 101 & 300 and above \\
\hline
\end{tabular}

The result of the study as shown in Table 4, the degree of risks 1, 3, 4 have reduce from serious risk to no risk through corrective action. Risks 2 from 360 reduced to 180 due to minimizing probability but it is still in serious risk zone. Risk number 5 from moderate risk level reduced to no risk. Risk number 6 has not changed and it is still in moderate level. Risk number 7 changed from moderate to no risk level and risk number 8 did not change and still in acceptable level. Table 6 shows the results of Table 5 for what elements has been changed (S, E and P).

Table 5 Identified risks for tool maintainers at their workplace are

\begin{tabular}{|c|c|c|c|c|c|}
\hline & $\begin{array}{l}\text { Identified } \\
\text { Risks }\end{array}$ & $\begin{array}{l}\text { Degree of } \\
\text { (R) Severity }\end{array}$ & $\begin{array}{l}\text { Recommended } \\
\text { Measure }\end{array}$ & Measured & $\begin{array}{l}\text { Reassessment } \\
\text { of }(\mathrm{R})\end{array}$ \\
\hline 1 & $\begin{array}{l}\text { Collision between } \\
\text { cranes because of } \\
\text { several cranes }\end{array}$ & 360 & $\begin{array}{l}\text { Collision } \\
\text { protection } \\
\text { between all } \\
\text { cranes }\end{array}$ & Done & 3 \\
\hline 2 & $\begin{array}{l}\text { Because of } \\
\text { cramped between } \\
\text { tools' table (tools } \\
\text { working bench) } \\
\text { there is a risk of } \\
\text { collision with the } \\
\text { other tool that } \\
\text { stand on its bench. }\end{array}$ & 360 & $\begin{array}{l}\text { Education, } \\
\text { information } \\
\text { about risk to } \\
\text { keep himself } \\
\text { away and make } \\
\text { sure no one } \\
\text { stays between } \\
\text { tools }\end{array}$ & Done & 180 \\
\hline 3 & $\begin{array}{l}\text { Work under } \\
\text { suspended load. }\end{array}$ & 180 & $\begin{array}{l}\text { Prepare stands } \\
\text { that tool can be } \\
\text { put on for } \\
\text { working under } \\
\text { tool }\end{array}$ & Done & 0,25 \\
\hline 4 & $\begin{array}{l}\text { During turning } \\
\text { tool, there will be } \\
\text { strong fold on } \\
\text { chain with wide } \\
\text { angle. }\end{array}$ & 120 & $\begin{array}{l}\text { Daily check of } \\
\text { crane and its } \\
\text { accessories } \\
\text { continuous } \\
\text { education and } \\
\text { information }\end{array}$ & Done & 4 \\
\hline
\end{tabular}


Table 5 (Continued)

\begin{tabular}{llllll}
\hline & $\begin{array}{l}\text { Identified } \\
\text { Risks }\end{array}$ & $\begin{array}{l}\text { Degree of } \\
\text { (R) Severity }\end{array}$ & $\begin{array}{l}\text { Recommended } \\
\text { Measure }\end{array}$ & $\begin{array}{l}\text { Reassessment } \\
\text { of (R) }\end{array}$ \\
\hline 5 & $\begin{array}{l}\text { Labeling tool } \\
\text { weight there is a } \\
\text { risk overloading } \\
\text { the crane } \\
\text { accessory }\end{array}$ & 80 & $\begin{array}{l}\text { Marking clearly } \\
\text { tool weights }\end{array}$ & Done & 2 \\
\hline 6 & $\begin{array}{l}\text { Lifting with } \\
\text { magnetic device. }\end{array}$ & 60 & $\begin{array}{l}\text { Information and } \\
\text { education take a } \\
\text { distance with } \\
\text { load }\end{array}$ & Done & 60 \\
& & $\begin{array}{l}\text { information } \\
\text { about the risks } \\
\text { or forbid to go } \\
\text { through the } \\
\text { workshop }\end{array}$ & Done & 0,25 \\
\hline 7 & $\begin{array}{l}\text { Other people who } \\
\text { walk in the hall } \\
\text { show very poor } \\
\text { respect to those } \\
\text { who drive crane. }\end{array}$ & 40 & $\begin{array}{l}\text { Information } \\
\text { about risk }\end{array}$ & Done & 16 \\
\hline 8 & & & & \\
\hline hisk of hitting the & 16 & & & \\
\hline
\end{tabular}

Table 6 Summary of the results

\begin{tabular}{lllll}
\hline $\begin{array}{l}\text { Risk } \\
\text { No }\end{array}$ & $\begin{array}{l}\text { Degree of } \\
\text { Severity }(\mathrm{R})\end{array}$ & $\begin{array}{l}\text { Reassessment } \\
\text { of }(\mathrm{R})\end{array}$ & $\begin{array}{l}\text { Change in } \\
\text { Factors }\end{array}$ & Results \\
\hline 1 & 360 & 3 & S, E and P & No risk \\
2 & 360 & 180 & P & Serious risk \\
3 & 180 & 0,25 & S, E and P & No risk \\
4 & 120 & 4 & S and E & No risk \\
5 & 80 & 2 & S and P & No risk \\
6 & 60 & 60 & No changes & Moderate risk \\
7 & 40 & 0,25 & S and E & No risk \\
8 & 16 & 16 & No changes & Acceptable risk \\
\hline
\end{tabular}

\section{Discussion}

The concept of safety first is digested and accepted nowadays in all industrial settings. In fact, safety depends also on the principle of EfficiencyThoroughness Trade-Off (ETTO). This (ETTO) has an important role for safety management system in the case of practical limitations such as, resources, time and effort. Understanding system is a key issue so that up to what extend its performance fill system designers' expectation and their value. Faulty design system may have negative side effects on health and safety for 
people involved as well as their internal and external environment. Designing well-functioning system required multi-disciplinary updated knowledge. Maximizing system's performance is a function of knowledge and ability to analysis hinders in detail. That is, using relevant evaluating tools is key factors for system's safety (technical functioning), human's health and safety and how assimilating system to the environmental requirement. Safety is a key factor in any organization. Inherently, every technology comprises of risks through their activities not only for their staff members also for environment. Therefore, it is essential to consider safety at the highest level for as much as possible things (activities) go right rather than go wrong in entire organizational activities. Organization policy need to establish the atmosphere for their employees to have feeling of being safe.

\section{Conclusion}

In this paper, two relevant tools, Hierarchical Task Analysis (HTA) and William Fine method were used to prevent serious accident and make tasks performances safer for maintainers. These two methods can be key issues during maintainability design process in order to make maintenance performance easier. Collaboration between managers and ergonomist in this study led to have better understanding of real work performance (work- as-down and work- as- imagine) both for operators and managers. HTA could exposed each sub task, needed skills and helped maintenance operators the sequences of their task's performance. Risks analysis detected related risks for tasks performances. Operators became aware of all level of risks and personal protective equipment were prepared within the manufacturing facility for precautions.

\section{References}

[1] http://cognitiveworkload.com/definitions/what-is-a-cognitive-task/

[2] K. Teymourian, D. Seneviratne, and D. Galar, "Ergonomics contribution in maintainability," Management Systems in Production Engineering, 2017, Vol.25(3), pp. 217-223.

[3] Hollnagel, Erik. Safety-I and Safety-II: The Past and Future of Safety Management, 2014.

[4] https://www.verywellmind.com/what-is-the-conscious-mind-2794984

[5] P. Senge, "https://www.youtube.com/watch?v=CeOZzMmIekw" 
[6] O. Gary, "Maintainability: Theory and Practice." System Health Management: With Aerospace Applications (2011): 309-317.

[7] B. S. Dhillon, "Engineering Maintainability," How to Design for Reliability and Easy Maintenance.

[8] B. S. Blanchard, D. Verma, E. L. Peterson (1995). "Maintainability" Willy Interscience ISBN 0-471-59132-7.

[9] M. Rausand, H. Arnljot, "System reliability theory" models, statistical methods, and applications (Vol. 396). John Wiley and Sons. (2004).

[10] Vorne, "https://www.oee.com/oee-six-big-losses.html".

[11] EUROCONTROL, "European Organisation for the Safety of Air Navigation" September 2013.

[12] https://www.merriam-webster.com/dictionary/intersubjective

[13] https://www.verywellmind.com/what-is-the-conscious-mind-2794984

[14] https://psychologydictionary.org/?s=Conscious+Minds

[15] https://www.dictionary.com/browse/accident?s=t

[16] https://en.oxforddictionaries.com/definition/accident

[17] https://en.oxforddictionaries.com/definition/incident

[18] Wilson, J., Haines, H., and Morris, W. (2005). Participatory ergonomics. In Evaluation of Human Work, 3rd Edition (pp. 927-956). CRC Press.

[19] Annett, J., 2004. Hierarchical task analysis. In: Diaper, D., Stanton, N.A. (Eds.), The Handbook of Task Analysis for Human-Computer Interaction. Lawrence Erlbaum Associates, Mahwah, NJ, pp. 67-82.

[20] N. A Stanton, "Human factors and ergonomics methods". In Handbook of human factors and ergonomics methods (pp. 27-38). CRC press (2004).

[21] A. Shepherd, "Hierarchical Task Analysis", Taylor and Francis, London (2002).

[22] K. Y. Lim, J. B. Long, "The MUSE method for usability engineering," (Vol. 8). Cambridge University Press (2009).

[23] C. Baber, N. A. Stanton, "Task analysis for error identification": a methodology for designing error-tolerant consumer products. Ergonomics, 37(11), 1923-1941.

[24] J. Annett, D. Cunningham, P. Mathias-Jones, P. (2000). "A method for measuring team skills". Ergonomics, 43(8), 1076-1094.

[25] Energy Institute, London, UK, 1 (2011). "Guidance on human factors safety critical task analysis". ISBN 978-0-85293-603-0.

[26] Annett, J., Duncan, K. D., Stammers, R. B., Gray, M. J., 1971. Task Analysis. Department of Employment Training Information Paper 6. HMSO, London. 
[27] Stanton, N. A. (2006). Hierarchical task analysis: Developments, applications, and extensions. Applied ergonomics, 37(1), 55-79.

[28] McAtamney, L., and Corlett, E. N. (1993). RULA: a survey method for the investigation of work-related upper limb disorders. Applied ergonomics, 24(2), 91-99.

[29] A. Hedge, E. Salas, N. A. Stanton, K. Brookhuis, H. W. Hendrick, (2004). Quick exposure checklist (QEC) for the assessment of workplace risks for work-related musculoskeletal disorders (WMSDs). In Handbook of human factors and ergonomics methods (pp. 74-85). CRC Press.

[30] S. Hignett, L. McAtamney, "Rapid entire body assessment". In Handbook of Human Factors and Ergonomics Methods (pp. 97-108). CRC Press (2004).

[31] W. T. Fine, "Mathematical evaluations for controlling hazards" (No. NOLTR-71-31). Naval Ordnance Lab White Oak Md (1971).

\section{Biographies}

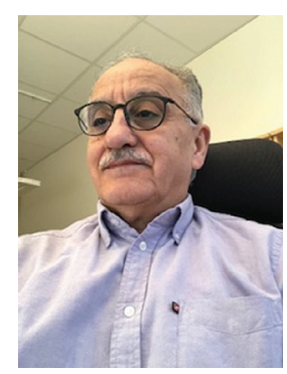

Kiumars Teymourian is a researcher in the Division of Operation and Maintenance at Luleå University of Technology, Luleå, Sweden. My research area is application of ergonomics/human factors in maintainability design process. I received my master degree (M.Sc.) and technical licentiate in industrial ergonomics at Luleå University. I was working many years in different industries as a mechanical engineer, ergonomist and health and safety responsible. 


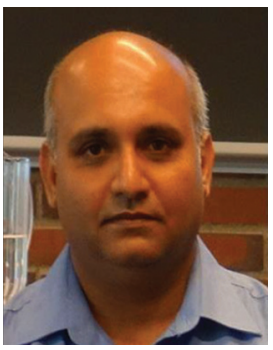

Dammika Seneviratne is a Researcher in Maintenance and Reliability engineering. He received his M.Sc. in Mechatronics Engineering from the Asian Institute of Technology, Thailand and $\mathrm{PhD}$ in Offshore Technology from the University of Stavanger. He was a Post-doctoral researcher in the Division of Operation and Maintenance, Luleå University of Technology, Luleå, Sweden. His research interests include condition monitoring, operation and maintenance engineering in engineering systems; risk based inspection planning in offshore oil and gas facilities; reliability and risk analysis and management, and risk based maintenance.

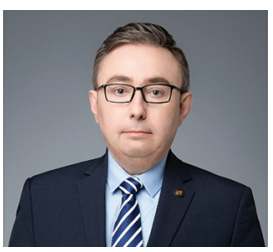

Diego Galar is Professor of Condition Monitoring in the Division of Operation and Maintenance Engineering at LTU, Luleå University of Technology where he is coordinating several $\mathrm{H} 2020$ projects related to different aspects of cyber physical systems, Industry 4.0, IoT or industrial Big Data. He was also involved in the SKF UTC centre located in Luleå focused on SMART bearings and also actively involved in national projects with the Swedish industry or funded by Swedish national agencies like Vinnova. He has been involved in the raw materials business of Scandinavia, especially with mining and oil and gas for Sweden and Norway respectively. Indeed, LKAB, Boliden or STATOIL have been partners or funders of projects in the CBM field for specific equipment like loaders, dumpers, rotating equipment, linear assets etc... 
He is also principal researcher in Tecnalia (Spain), heading the Maintenance and Reliability research group within the Division of Industry and Transport.

He has authored more than five hundred journal and conference papers, books and technical reports in the field of maintenance, working also as member of editorial boards, scientific committees and chairing international journals and conferences and actively participating in national and international committees for standardization and R\&D in the topics of reliability and maintenance.

In the international arena, he has been visiting Professor in the Polytechnic of Braganza (Portugal), University of Valencia and NIU (USA) and the Universidad Pontificia Católica de Chile. Currently, he is visiting professor in University of Sunderland (UK), University of Maryland (USA), University of Stavanger (NOR) and Chongqing University in China. 
